\title{
PENGARUH MODEL PEMBELAJARAN COURSE REVIEW HORAY TERHADAP HASIL BELAJAR SISWA PADA MATA PELAJARAN BIOLOGI DI MA SABILULHASANAH
}

\author{
Yulia Tri Samiha ${ }^{1}$, Syarifah $^{2}$, Puput Maryati ${ }^{3}$ \\ ${ }^{1,2,3}$ Pendidikan Biologi Fakultas Tarbiyah dan Keguruan, UIN Raden Fatah, Palembang \\ e-mail: yuliatrisamiha_uin@radenfatah.ac.id
}

\begin{abstract}
ABSTRAK
Masalah yang perlu kita selesaikan di dunia pendidikan kita adalah lemahnya proses belajar. Proses pembelajaran di kelas masih diarahkan pada kemampuan anak untuk menghafal informasi. Sementara biologi membutuhkan pembelajaran yang logis dan masuk akal untuk dapat diterima dan diserap oleh otak sehingga bisa bertahan lama. Tujuan dari penelitian ini adalah untuk mengetahui pengaruh pembelajran course review kursus horay terhadap hasil belajar kognitif siswa pada materi pelajaran sel di MA Sabilul Hasanah Kecamatan Sembawa Kabupaten Banyuasin. Metode penelitian ini menggunakan desain quasi eksperimen dengan pendekatan kuantitatif penelitian pretest-posttest control group design. Sampel diambil dengan menggunakan teknik purposive sampling. Sampel adalah kelas XI MIA 2 sebagai kelas eksperimen dan kelas XI MIA 1 sebagai kelas kontrol. Instrumen yang digunakan dalam penelitian ini adalah tes untuk mengukur pembelajaran kognitif siswa tentang kategori kognitif C1C4. Analisis data menggunakan uji-t, data pada perbedaan perhitungan rata-rata posttest kedua kelompok memperoleh nilai uji-t sebanyak 4,806 sedangkan nilai ttabel dengan taraf signifikan 5\% dengan derajat kebebasan (dk) 42 sama dengan 1,684, dapat dikatakan bahwa uji-t $>$ t-tabel berarti hipotesis alternatif $\left(\mathrm{H}_{\mathrm{a}}\right)$ diterima dan hipotesis nol $\left(\mathrm{H}_{0}\right)$ ditolak. Dapat disimpulkan bahwa ada pengaruh yang signifikan pembelajran course review kursus horay terhadap hasil belajar kognitif siswa pada materi pelajaran sel di MA Sabilul Hasanah.
\end{abstract}

Kata kunci: Course review horay, pembelajaran kognitif siswa.

\section{ABSTRACT}

The problem that we need to be solved in the world of our education is the weak learning process. The learning process in the classroom is still directed at the child's ability to memorize information. While biology requires logical and reasonable learning to be accepted and absorbed by the brain so that it can last long. The aim of the research is to know the influence of course review horay learning toward student's of cognitive learning class ten in the subject matter cell in MA Sabilul Hasanah Kecamatan Sembawa Kabupaten Banyuasin. This research method used quasiexperimental design with a quantitative approach research pretest-posttest control group design. The sample is taken by using purposive sampling techniques. The sample was grade XI MIA 2 as an experimental class and class XI MIA 1 as the control class. The instrument used in this research is a test to measure student's cognitive learning about the cognitive categories C1-C4. Data analysis use the t-test, data on the calculation difference average posttest both groups earned value t-test much as 4,806 while value t-table with significant level5\% with degrees of freedom (dk) 42 is equal to1,684, it can be said that t-test $>\mathrm{t}$-table means the alternative hypothesis $\left(\mathrm{H}_{\mathrm{a}}\right)$ be accepted and the null hypothesis $\left(\mathrm{H}_{0}\right)$ rejected. It can be concluded that there is a significant influence of course review horay learning toward student's of cognitive learning class eleven in the subject matter cell inMA Sabilul Hasanah.

Keyword: Course review horay, student's cognitive learning. 
Vol. 04, No. 01 : Hal. 29 - 37

Februari 2019

P-ISSN: 2528-679X

E-ISSN: 2597-9833

\section{PENDAHULUAN}

Pendidikan adalah usaha sadar dan terencana untuk mewujudkan suasana belajar dan proses pembelajaran. Tujuan pendidikanadalah agar peserta didik secara aktif mengembangkan potensi dirinya untukmemiliki kekuatan spiritual keagamaan, pengendalian diri, kepribadian, kecerdasan, akhlak mulia, serta keterampilan yang diperlukan dirinya, masyarakat, bangsa, dan negara (Depdiknas, 2003).

Pendidikan di Sekolah Menengah Atas (SMA) mengajarkan banyak mata pelajaran, dan salah satunya adalah biologi. Biologi adalah bagian dari ilmu sains yang membahas mengenai kehidupan dan menjadi subyek mata pelajaran di sekolah. Mempelajari biologi akan membangkitkan pengertian dan rasa sayang pada makhluk hidup, rasa peduli pada lingkungan hidup, mengembangkan cara berpikir ilmiah melalui penelitian, serta membangkitkan rasa syukur atas kekuasaan Allah dalam menciptakan segala sesuatu. Herdani dkk (2015) menyatakan bahwa biologi merupakan salah satu cabang ilmu pengetahuan alam yang dipelajari pada tingkat pendidikan menengah atas (SMA). Biologi mempelajari tentang seluruh aspek kehidupan dan berkaitan erat dengan kehidupan sehari-hari.

Menurut Susanto (2013), salah satu masalah yang dihadapi dunia pendidikan kita adalah masalah lemahnya proses pembelajaran. Proses pembelajaran di kelas masih diarahkan kepada kemampuan anak untuk menghafal informasi. Pendidikan di sekolah terlalu memaksa otak anak dengan berbagai bahan ajar yang harus dihafal. Pada kenyataanya, biologi bukan hanya sekedar penghafalan informasi saja, namun juga disertai dengan pemahaman konsep dan pengaplikasiannya dalam kehidupan sehari-hari. Kebanyakan siswa di sekolah masih hanya menerima informasi dan mengingatnya saja. Padahal jika hanya mengingat-ingat saja, materi tersebut tidak akan bertahan lama dan akan cepat lupa. Biologi memerlukan keterampilan berpikir logis. Sesuatu yang logis dan masuk akal cepat diterima dan diserap otak sehingga bisa bertahan lama.

Mengajar yang baik dilakukan dengan sepenuh hati, ikhlas, inovatif, memunculkan motivasi, memunculkan minat, dan tentunya memunculkan bakat. Oleh karena itu, pemakaian metode ataupun model pembelajaran sangat diperlukan agar proses penyampaian dan transferasi ilmu dapat berjalan seperti yang diharapkan. Pembelajaran yang daapt menimbulkan rasa senang selama proses pembelajaran berlangsung dapat memotivasi siswa untuk meningkatkan prestasi belajar(Suparman, 2010)

Berdasarkan hasil observasi di MA Sabilul Hasanah diperoleh informasi bahwa pada proses pembelajaran biologi, selama ini guru masih menggunakan metode ceramah. Metode ini membuat siswa lebih cenderung pasif, dan pelaksanaan pembelajaran terpaku pada guru, karena siswa kurang ikut berpartisipasi, hanya duduk, mendengar, mencatat, dan menghafal.

Berdasarkan hasil observasi tersebut, maka diperlukan sebuah alternatif pembelajaran yang dapat meningkatkan pemahaman konsep siswa dalam belajar sehingga pencapaian kompetensi pada ranah kognitif dapat tercapai sesuai dengan kriteria ketuntasan minimal yang telah di tetapkan. Dalam menyampaikan teori, guru harus pandai membawa suasana sehingga siswa tertarik untuk mendengarkan. Selain itu, guru juga dituntut untuk dapat memilih model dan metode yang dapat membuat 
Vol. 04, No. 01 : Hal. 29 - 37

Februari 2019

P-ISSN: 2528-679X

E-ISSN: 2597-9833

siswa aktif dalam proses pembelajaran. Dari berbagai model pembelajaran yang ada, terdapat model pembelajaran yang dapat meningkatkan pemahaman konsep siswa yaitu model pembelajaran Course Review Horay.

Model pembelajaran Course Review Horay merupakan model pembelajaran yang dapat menciptakan suasana kelas menjadi meriah dan menyenangkan karena setiap siswa yang dapat menjawab benar maka siswa tersebut diwajibkan berteriak "hore!" atau yel-yel lainnya yang disepakati. Pembelajaran Course Review Horay merupakan salah satu pembelajaran kooperatif yaitu kegiatan belajar mengajar dengan cara pengelompokkan siswa ke dalam kelompok-kelompok kecil. Pembelajaran Course Review Horay merupakan suatu pembelajaran pengujian terhadap pemahaman konsep siswa menggunakan kotak yang diisi dengan soal dan diberi nomor untuk menuliskan jawabannya. Siswa yang paling terdahulu mendapatkan tanda benar langsung berteriak horay atau yel-yel kelompoknya. Melalui pembelajaran Course Review Horay diharapkan dapat melatih siswa dalam menyelesaikan masalah. Dengan model course review horay, siswa dapat memahami materi yang telah diberikan dengan mudah (Neufeld dan Deralnik, 1995).

Pembelajaran dengan menggunakan model pembelajaran Course Review Horay dinilai memiliki berbagai keunggulan hal ini dikarenakan dengan model pembelajaran Course Review Horay diharapkan siswa lebih semangat dalam belajar karena pembelajarannya tidak monoton diselingi sedikit hiburan sehingga suasana tidak menegangkan. Selain itu pembelajarannya menarik dan mendorong siswa untuk dapat terjun langsung ke dalamnya serta melatih kerjasama siswa dengan begitu penyampaian teori tidak akan monoton, sehingga dapat menarik perhatian siswa untuk fokus pada pelajaran tersebut sehingga tingkat pemahaman siswa menjadi lebih optimal (Neufeld dan Deralnik, 1995).

Penelitian terdahulu yang relevan dengan model pembelajaran Course Review Horay adalah penelitian Putri dkk(2017), hasil penelitian menunjukkan bahwa penggunaan metode Course Review Horay efektif untuk meningkatkan keterampilan berhitung anak dengan retardasi mental ringan di kelas IV SLB Negeri Surakarta dalamtahun akademik 2016/2017. Rini dkk (2017), hasil penelitian menunjukkan bahwa model pembelajaran CRH berbasis Pendekatan PBL telah meningkatkan keterampilan berpikir kritis siswa dan secara signifikan meningkatkan hasil belajar siswa dari kognitif, afektif dan psikomotorik. Ritonga dan Tanjung (2014), hasil penelitian menunjukkan bahwa model pembelajaran kooperatiffisika $\mathrm{CRH}$ meningkatkan hasil belajar siswa dalam materi pelajaransuhu dan panas kelas $\mathrm{X}$ Semester II MAN Kisaran.

Berdasarkan uraian di atas, maka akan dilakukan percobaan untuk menerapkan sistem pembelajaran dengan menggunakan model pembelajaran Course Review Horay dan akan dilihat pengaruhnya terhadap hasil belajar kognitif siswa kelas XI MA Sabilul Hasanah.

\section{METODOLOGI PENELITIAN}

Penelitian ini merupakan penelitian kuantitatif. Penelitian termasuk dalam Quasi Experimental Design dengan rancangan Pretest-Posttest Control Group Design. Rancangan Penelitian dapat dilihat pada Gambar 1. 
Vol. 04, No. 01 : Hal. 29 - 37

Februari 2019

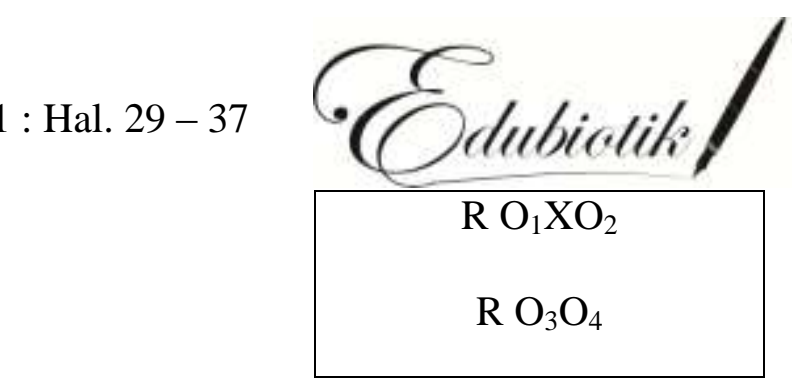

P-ISSN: 2528-679X

E-ISSN: 2597-9833

Gambar 1. Rancangan Penelitian Pretest-PosttestControl Group Design

(Sumber: Sugiyono, 2012)

Keterangan:

R: Kelompok eksperimen dan kontrol

$\mathrm{X}$ : Perlakuan

$\mathrm{O}_{1:}$ Pretest kelompok kelas eksperimen

$\mathrm{O}_{3 \text { : }}$ Pretest kelompok kelas kontrol

$\mathrm{O}_{2:}$ Hasilposttest siswa kelas eksperimen

$\mathrm{O}_{4:}$ Hasilposttest siswa kelas kontrol

Penelitian dilakukan di MA Sabilul Hasanah pada tanggal 5-28 Agustus 2017. Populasi dalam penelitian adalah seluruh siswa kelas XI MIA di MA Sabilul Hasanah tahun ajaran 2017/2018. Sampel penelitian adalah siswa kelas XI MIA 2 sebanyak 23 siswa sebagai kelas eksperimen dan kelas XI MIA 1 sebanyak 21 siswa sebagai kelas kontrol.

Teknik pengumpulan data menggunakan tes tertulis,angket,dan dokumentasi.Instrumen penelitian yang digunakan adalah tes dan angket. Tes akan diberikan sebelum pembelajaran (pretest) dan sesudah pembelajaran (postest) untuk mengetahui hasil belajar siswa. Lembar angket digunakan sebagai data pendukung yang digunakan untuk mengetahui respon siswa terhadap penerapan model pembelajaran Course Review Horay terhadap hasil belajar kognitif siswa.Teknik analisis data menggunakan uji normalitas, uji homogenitas, dan uji-t (Sugiyono, 2012).

\section{HASIL DAN PEMBAHASAN \\ Data Hasil Pretest}

Berdasarkan hasil pretest, diketahui nilai rata-ratapretest kelas eksperimen adalah 16,52 dan kelas kontrol adalah 18,81 (Gambar 2)yang berarti tidak jauh berbeda perbandingan keduanya.

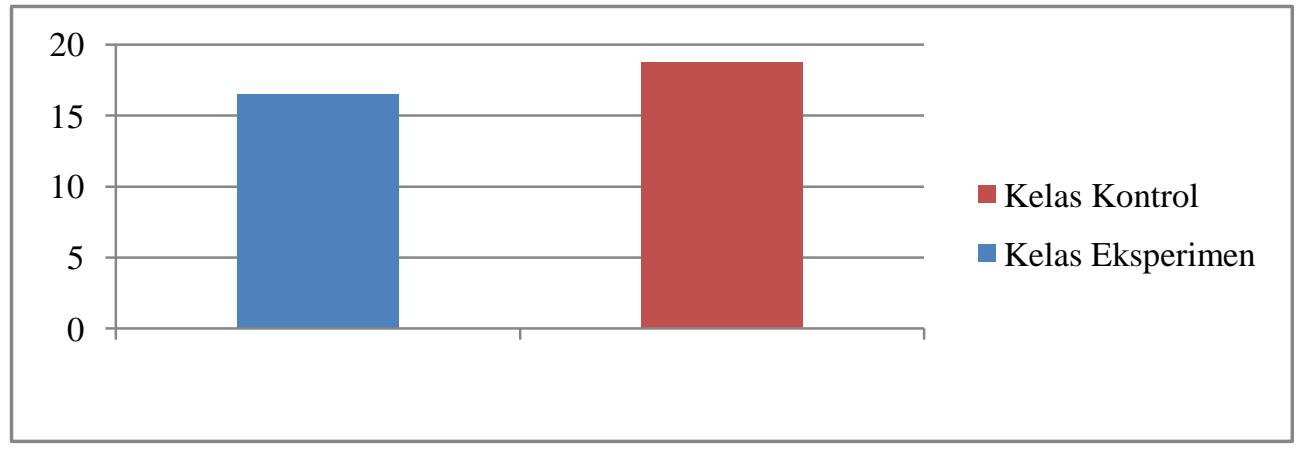

Gambar 2. Grafik Skor Rata-Rata Pretest

\section{Data Hasil Posttest}

Berdasarkan hasil posttest, diketahuinilai rata-rata posttest pada kelas eksperimenadalah 79,07 sedangkan ratarata posttest pada kelas kontrol adalah 68,64 (Gambar 3). Rata-rata kelas eksperimenlebih tinggi dibandingkan dengan kelas kontrol $(79,07>68,64)$. Hal ini menunjukkan bahwa kelas eksperimen memiliki kemampuan penguasaan materi yang lebih baik dibandingkan dengan kelas kontrol. 
Vol. 04, No. 01 : Hal. 29 - 37

Februari 2019

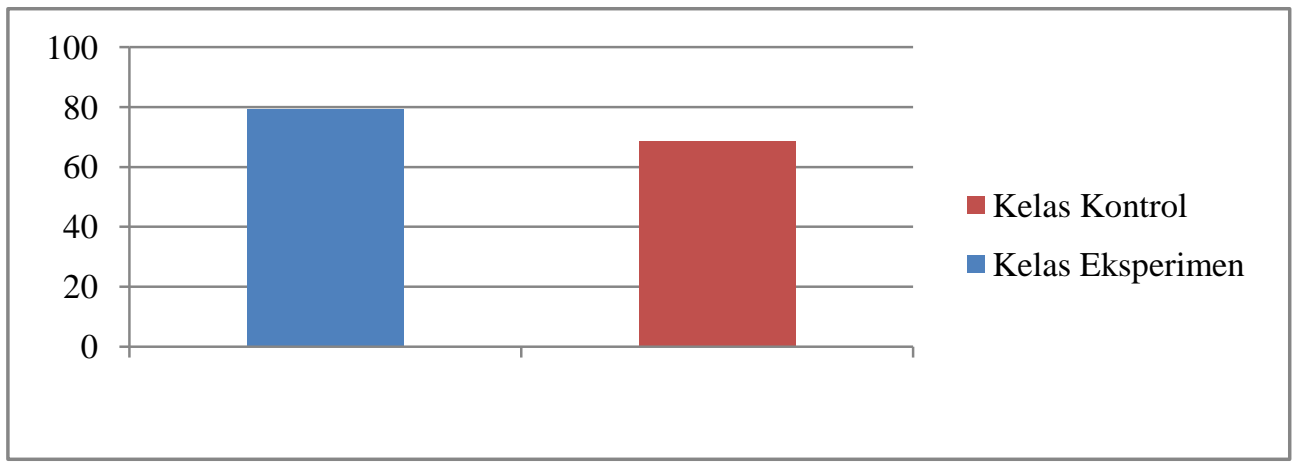

\section{Normal Gain (N-Gain)}

Gambar 3. Grafik Skor Rata-Rata Posttest

Gain adalah selisih antara nilai posttest dan pretest. Gain menunjukkan peningkatan pemahaman atau penguasaan konsep siswa setelah pembelajaran dilakukan oleh guru. Tinggi rendahnya gain yang dinormalisasi (N-gain) dapat diklasifikasikan sebagai berikut: (1) jika $g \geq$
0,7 , maka $\mathrm{N}$-gain yang dihasilkan termasuk kategori tinggi; (2) jika $0,7>\mathrm{g} \geq 0,3$, maka $\mathrm{N}$-gain yang dihasilkan termasuk kategori sedang, dan (3) jika g < 0,3 maka $\mathrm{N}$-gain yang dihasilkan termasuk kategori rendah (Hake, 2017). Rekapitulasi hasil N-gain dari hasil penelitian ditunjukkan pada Tabel 1 sebagai berikut.

Tabel 1. Rekapitulasi Hasil N-Gain

\begin{tabular}{|c|c|c|c|}
\hline \multirow[t]{2}{*}{ Kelas } & \multicolumn{2}{|c|}{ Rata-Rata } & \multirow[t]{2}{*}{ N-Gain } \\
\hline & Pretest & Posttest & \\
\hline Eksperimen & 16,52 & 79,07 & 0,75 \\
\hline Kontrol & 18,18 & 68,64 & 0,61 \\
\hline
\end{tabular}

Berdasarkan Tabel 1, dapat dilihat $\mathrm{N}$-Gainkelas eksperimen adalah 0,75 sedangkan nilai N-Gain kelas kontrol sebesar 0,61. Dari nilai N-Gain kelas eksperimen diketahui bahwa nilai $\mathrm{g} \geq 0,7$ maka $\mathrm{N}$-gain yang dihasilkan termasuk kategori tinggi. Sedangkan kelas kontrol diketahui bahwa nilai $0,7>\mathrm{g} \geq 0,3$ maka $\mathrm{N}$ gain yang dihasilkan termasuk kategori sedang. Hal ini menunjukkan besarnya peningkatan hasil belajar kognitif pada kelas eksperimen lebih besar dari kelas kontrol.

\section{Pengujian Prasyarat Analisis Data}

Sebelum dilaksanakan pengujian hipotesis, maka terlebih dahulu dilaksanakan pengujian prasyarat uji normalitas dan uji homogenitas.

Uji normalitas bertujuan untuk mengetahui apakah sampel yang digunakan berdistribusi normal atau tidak.Data dapat dikatakan berdistribusi normal apabila harga $K m$ terletak antara -1 dan +1 dalam selang $(1<K m<+1)$ (Sugiyono, 2012). Rekapitulasi hasil uji normalitas dapat di lihat pada Tabel 2 .

Tabel 2. Rekapitulasi Hasil Uji Normalitas

\begin{tabular}{ccccccc}
\hline Data & Kelompok & $\overline{\mathbf{X}}$ & Mo & S & Km & Keterangan \\
\hline \multirow{2}{*}{ Pretest } & Eksperimen & 16,52 & 15 & 6,82 & 0,22 & Normal \\
& Kontrol & 18,81 & 15,50 & 7,23 & 0,46 & Normal \\
\multirow{2}{*}{ Posttest } & Eksperimen & 79,07 & 77,93 & 6,82 & 0,17 & Normal \\
& Kontrol & 68,64 & 67,23 & 7,50 & 0,19 & Normal \\
\hline
\end{tabular}

Berdasarkan hasil uji normalitas (Tabel 2) data pretest dan posttest dari kelompok eksperimen dan kelompok kontrol dapat disimpulkan bahwa data yang 
Vol. 04, No. 01 : Hal. 29 - 37

Februari 2019

P-ISSN: 2528-679X

E-ISSN: 2597-9833

diperoleh berdistribusi normal. Hal tersebut menunjukkan bahwa sampel yang digunakan dalam penelitian ini berasal dari populasi yang berdistribusi normal.

Uji homogenitas varians bertujuan untuk mengetahui apakah kedua kelompok data sampel mempunyai varians yang homogen atau tidak. Hal ini sesuai dengan pernyataanYusuf (2015), bahwa uji homogenitas sangat diperlukan untuk

membuktikan data dasar yang akan diolah adalah homogen, sehingga segalabentuk pembuktian menggambarkan yang sesungguhnya, bukan dipengaruhi oleh variansi yang terdapat dalam data yang akan diolah. Uji homogenitas varians dilakukan dengan uji F(Sugiyono, 2012). Rekapitulasi hasil uji homogenitas dapat di lihat pada Tabel 3.

Tabel 3. Rekapitulasi Hasil Uji Homogenitas

\begin{tabular}{cccccc}
\hline Jenis Data & $\alpha$ & $\mathbf{F}_{\text {hitung }}$ & $\mathbf{F}_{\text {tabel }}$ & Hasil Data & Keterangan \\
\hline Pretest & 0,05 & 1,125 & 4,07 & $\mathrm{~F}_{\text {hitung }}<\mathrm{F}_{\text {tabel }}$ & Homogen \\
Posttest & 0,05 & 1,208 & 4,07 & $\mathrm{~F}_{\text {hitung }}<\mathrm{F}_{\text {tabel }}$ & Homogen \\
\hline
\end{tabular}

Berdasarkan Tabel 3 diketahui bahwa hasil perhitungan uji homogenitas data pretest dan posttest pada kelompok kontrol dan eksperimen di dapat hasil bahwa $F_{\text {hitung }}<F_{\text {tabel. }}$ Hal ini menunjukkan bahwa pada taraf signifikan $\alpha=0,05$ (5\%) dapat disimpulkan bahwa kedua sampel tersebut berasal dari populasi yang berdistribusi homogen.

\section{Uji Hipotesis}

Setelah dilakukan uji normalitasdan uji homogenitas, diketahui bahwa kedua kelompok berdistribusi normal dan homogen. Selanjutnya adalah pengujian hipotesis menggunakan uji-t.

Uji-t dilakukan bertujuan untuk mengetahui apakah terdapat perbedaan ratarata antara kelas eksperimendan kelas kontrol. Uji ini dilakukan dengan membandingkan hasil postest pada kelompok eksperimendan kontrol (Sugiyono, 2012).

Tabel 4. Rekapitulasi Perhitungan Uji-tPosttest

\begin{tabular}{ccccccc}
\hline Kelompok & $\alpha$ & $\mathbf{d k}$ & $\mathbf{t}_{\text {hitung }}$ & $\mathbf{t}_{\text {tabel }}$ & Keputusan & Keterangan \\
\hline $\begin{array}{c}\text { Eksperimen } \\
\text { Kontrol }\end{array}$ & 0,05 & 42 & 4,806 & 1,684 & Terima $\mathrm{H}_{\mathrm{a}}$ & \multirow{2}{*}{ Berbeda Signifikan } \\
\hline
\end{tabular}

Berdasarkan Tabel 4 diperoleh $t_{\text {hitung }}$ $=4,806>\mathrm{t}_{\text {tabel }}=1,684$, maka hipotesis nol $\left(\mathrm{H}_{\mathrm{o}}\right)$ ditolak. Dengan demikian dapat disimpulkan bahwa terdapat perbedaan yang signifikan antara kelompok kontrol dan eksperimen. Hal ini menunjukkan bahwa model pembelajaran Course Review Horay berpengaruh terhadap hasil belajar kognitif siswa dilihat dari nilai rata-rata tes akhir (posttest) siswa pada kelompok eksperimen yang lebih tinggi yaitu sebesar 79,07 dibandingkan dengan nilai rata-rata posttest kelompok kontrol yaitu sebesar 68,64 .

Berdasarkan data pretest kelas eksperimendan kelas kontrol menunjukkan bahwa tidak terdapat perbedaan hasil belajar yang signifikan antara kelas eksperimendan kelas kontrol. Hal ini menunjukkan bahwa siswa kelas eksperimen dan kelas kontrol memiliki kemampuan awal yang sama. Data hasil pretest menunjukkan bahwa rata-rata nilai pretest pada kelas eksperimenadalah 16,52. 
Vol. 04, No. 01 : Hal. 29 - 37

Februari 2019

P-ISSN: 2528-679X

E-ISSN: 2597-9833

Sedangkan rata-rata nilai pretest pada kelas kontrol adalah 18,81. Rendahnya rata-rata pretest ini disebabkan karena materi yang diujikan belum diajarkan kepada siswa, sehingga siswa menjawab pertanyaan sesuai pengalaman siswa dalam kehidupan seharihari. Perbedaan rata-rata kelompok kontrol dan kelompok eksperimen tidak berpengaruh terhadap hasil uji homogenitas pretestkelas eksperimendan kelaskontrol yang menyatakan bahwa kedua kelompok homogen.

Setelah diterapkan model pembelajaran Course Review Horay pada kelompok eksperimendan pembelajaran konvensional pada kelompok kontrol. Maka dilakukan tes tertulis pada akhir pembelajaran (posttes). Nilai rata-rata posttest pada kelompok eksperimen sebesar 79,07. Sedangkan rata-rata posttest pada kelompok kontrol setelah diterapkan pembelajaran konvensional adalah 68,64. Rata-rata kelompok eksperimen lebih tinggi dibandingkan dengan kelompok kontrol (79,07> 68,64). Tingginya rata-rata pada kelompok eksperimen disebabkan karena dalam pembelajaran Course Review Horay, siswa dilatih untuk menyelesaikan permasalahan dengan caya menyenangkan. Hal ini sesuai dengan penyataan Neufeld dan Deralnik (1995), bahwa dalam metode pembelajaran Course Review Horaysiswa benar-benar dilatih untuk memecahkan suatu permasalahan dan dievaluasi dengan cara menyenangkan, sehingga siswa dapat memahami materi yang telah diberikan dengan mudah. Model Course Review Horay menerapkan pembelajaran sekaligus hiburan sehingga siswa dapat memahami materi yang telah diberikan dengan mudah. Pemahaman siswa tentang materi yang bersangkutan dievaluasi dengan carayang menyenangkan, sehingga dapat meningkatkan semangat belajar siswa.
Proses pembelajaran dalam penelitian menunjukkan terdapat perbedaan hasil belajar kognitif antara kelas yang diberikan perlakuan dengan menerapkan model pembelajaran Course Review Horaydengan kelas yang diberikan perlakuan dengan menerapkan metode ceramah. Hal tersebut dapat dilihat dari hasil belajar siswa pada analisis perhitungan hasil belajar kognitif siswa dengan menggunakan perhitungan uji-t. Uji ini dilakukan dengan membandingkan hasil posttest pada kelas eksperimendan kelas kontrol dengan menggunakan taraf signifikansi $(\alpha)$ sebesar $5 \%$ atau 0,05 .

Berdasarkan pengujian hipotesis terhadap data posttest kelompok eksperimen dan kontrol dengan menggunakan uji-t (Tabel 4)Diketahui bahwa terdapat perbedaan hasil belajar yang signifikan antara kelompok eksperimen dan kontrol. Hal ini dibuktikan dengan nilai $t_{\text {hitung }}$ lebih besar dari $t_{\text {tabel }}$ $\left(\mathrm{t}_{\text {hitung }}=4,806>\mathrm{t}_{\text {tabel }}=1,684\right)$. Perbedaan hasil belajar dapat terjadi karena proses pembelajaran pada kelas eksperimen menggunakan model Course Review Horay. Model ini menerapkan pembelajaran sekaligus hiburan, sehingga membuat siswa lebih bersemangat dalam belajar dan tidak mengalami kejenuhan dalam proses belajar. Sedangkan pada kelas kontrol menggunakan metode ceramah, dimana proses pembelajaran berpusat pada informasi yang disampaikan oleh guru sehingga siswa mengalami kejenuhan dalam proses belajar. Dengan demikian dapat disimpulkan bahwa terdapat perbedaan rata-rata yang signifikan antara kedua data, maka $\mathrm{H}_{0}$ ditolak dan $\mathrm{H}_{\mathrm{a}}$ ditrima. Dalam hal ini menunjukkan bahwa ada pengaruh penerapan model pembelajaran Course Review Horay terhadap hasil belajar kognitif siswa pada materi Sel. 
Vol. 04, No. 01 : Hal. 29 - 37

Februari 2019

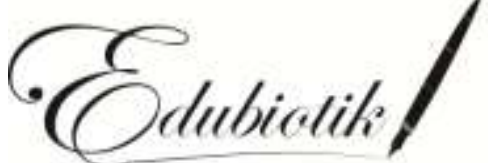

P-ISSN: 2528-679X

E-ISSN: 2597-9833

Berdasarkan hasil penelitian diketahui bahwa model Course Review Horaydapat meningkatkan hasil belajar kognitif siswa karena proses penyampaian materi dilakukan dengan cara menyenangkan, melibatkan partisipasi siswa, sehingga siswa dapat dengan mudah mengikuti proses pembelajaran dan memahami isi dari materi yang disampaikan oleh guru. Sebagaimana yang diungkapkan oleh Kurniasih dan Sam, (2015), bahwa model pembelajaran Course Review Horay dapat menarik dan mendorong siswa untuk dapat berpartisipasi langsung selama proses pembelajaran, melatih kerja sama antarsiswa di dalam kelas, pelajaran tidak monoton karena diselingi dengan hiburan sehingga suasana tidak menegangkan, dan siswa lebih semangat belajar karena suasana pembelajaran berlangung menyenangkan. Kebutuhan objek belajar menggunakan model dirasa sesuai dengan materi pelajaran yang akan diberikan, contohnya pada mata pelajaran Biologi. Pelajaran tersebut cocok dengan model ini, siswa dapat lebih mudah mengingat materi yang telah disampaikan oleh guru dan juga istilah-istilah yang ada dalam pelajaran tersebut.

Mulyasa (2008) mengemukakan bahwa peran guru sebagai fasilitator, dalam hal ini guru hendaknya dapat memberikan kemudahan kepada peserta didik agar anak didik belajar dalam suasana menyenangkan, gembira, penuh semangat, dan berani mengemukakan pendapat secara terbuka. Dengan demikian dapat menjadi modal dasar bagi peserta didik untuk tumbuh dan berkembang menjadi manusia yang siap beradaptasi, menghadapi berbagai kemungkinan dan memasuki era globalisasi yang penuh berbagai tantangan. Kemudian guru sebagai motivator, dalam hal ini guru harus mampu membangkitkan semangat

belajar peserta didik sehingga mencapai tujuan pembelajaran.

Secara keseluruhan penerapan model pembelajaran course review horaypada materi sel berpengaruh positif terhadap proses dan hasil pembelajaran karena selain dapat meningkatkan hasil belajar siswa, juga dapat melatih dan membantu siswa untuk lebih aktif, berpikir kritis, melatih siswa untuk memecahkan suatu permasalahan, serta melatih kerja sama antar siswa di dalam kelas.

\section{SIMPULAN DAN SARAN}

Pelaksanaan model pembelajaran Course Review Horayyang diterapkan di kelas eksperimen sudah berlangsung cukup baik. Para peserta didik terlihat sangat senang dan tidak merasa bosan dalam proses pembelajaran. Hal ini disebabkankan karena model pembelajaran Course Review Horay merupakan model pembelajaran yang dapat menciptakan suasana kelas menjadi meriah dan menyenangkan.

Data hasil pretest menunjukkan bahwa rata-rata nilai pretest kelas eksperimen adalah 16,52 dan rata-rata nilai pretest kelas kontrol adalah 18,81. Sedangkan nilai rata-rata posttest kelas eksperimen adalah 79,07 dan nilai rata-rata posttest kelas kontrol adalah 68,64. Nilai rata-rata kelas eksperimen lebih tinggi dibandingkan dengan kelas kontrol $(79,07>$ 68,64). Hal ini menunjukan bahwa kelas eksperimen memiliki penguasaan materi yang lebih baik dibandingkan dengan kelas kontrol.

Berdasarkan hasil perhitungan uji-t data posttest dengannilai $t_{\text {hitung }} 4,806$ lebih besar dibandingkan dengan nilai $t_{\text {tabel }} 1,684$ $\left(\mathrm{t}_{\text {hitung }}=4,806>\mathrm{t}_{\text {tabel }}=1,684\right)$, hal tersebut menunjukkan bahwa $\mathrm{H}_{0}$ ditolak dan $\mathrm{H}_{\mathrm{a}}$ diterima. Sehingga dapat disimpulkan bahwa terdapat pengaruh penerapan model 
Vol. 04, No. 01 : Hal. 29 - 37

Februari 2019

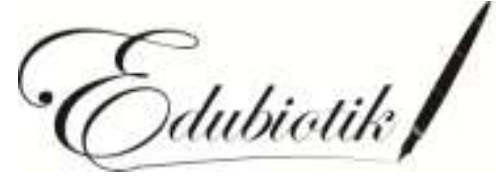

P-ISSN: 2528-679X

E-ISSN: 2597-9833

pembelajaran Course Review Horay terhadap hasil belajar kognitif siswa.

Saran bagi guru, bahwa model pembelajaran Course Review Horay dapat dipraktekkan dalam proses pembelajaran di kelas karena mampu meningkatkan hasil belajar siswa terutama pada ranah kognitif siswa. Bagi peneliti, diharapkan dapat melakukan modifikasi dan implementasi model pembelajaran Course Review Horaydalam pembelajaran biologi, misalkan dipadukan dengan strategi pembelajaran atau media pembelajaran yang berbeda dan sesuai dengan karakteristik peserta didik yang diajar.

\section{RUJUKAN}

Depdiknas. (2003). Undang-Undang Sistem Pendidikan Nasional. Jakarta: Departemen Pendidikan Nasional.

Hake, R. R. (2017). Design-Based Research in Physics Education Research: A Review," in A.E. Kelly, R.A. Lesh, \& J.Y. Baek, eds. (In Press), Handbook of Design Research Methods in Mathematics, Science, and Technology Education. Erlbaum: online at $<$ http://www.physics.indiana.edu/ hak e/DBR-Physics3.pdf $>$.

Herdani, T. P., Sartono, N., Evriyani, D. (2015). Pengembangan Permainan Monopoli Termodifikasi sebagai Media Pembelajaran pada Materi Sistem Hormon (Penelitian dan Pengembangan di SMAN 1 Jakarta). Jurnal Biosfer, 8(1), 20-28.

Kurniasih, I. dan Sam, B. (2015). Pengembangan Model Pembelajaran Untuk Peningkatan Profesionalitas Guru. Jakarta: Kata Pena.

Mulyasa. (2008). Standar Kompetensi dan Sertifikasi Guru. Bandung: Remaja Rosdakarya.

Neufeld, V. dan Deralnik, D. B. (1995). Webster's New Wordl College Dictionary and Course Review Horay. USA: Macmillan.

Putri, N. D. A., Salim, A. dan Sunardi. 